\title{
Nörobilim Yaklaşımıyla Girişimcilikte Farklı Bir Boyut: Nörogirişimcilik
}

\author{
Abdullah Ball1 ${ }^{1}$, Ali Ayc1 ${ }^{2}$ \\ 1, Milli Savunma Bakanlığı, Ankara, Türkiye, (ORCID: 0000-0003-2689-6610), dr1240201073@gmail.com \\ ${ }^{2}$ Ankara Yıldırım Beyazıt Üniversitesi, İşletme Fakültesi, Uluslararası Ticaret ve İşletmecilik Bölümü, Ankara, Türkiye (ORCID: 0000-0001-8173-1152), \\ aayci@ybu.edu.tr
}

(İlk Geliş Tarihi Aralık 2020 ve Kabul Tarihi Ocak 2021)

(DOI: $10.31590 /$ ejosat.849788)

\begin{abstract}
ATIF/REFERENCE: Ballı, A., Aycı, A., (2021). Nörobilim Yaklaşımıyla Girişimcilikte Farklı Bir Boyut: Nörogirişimcilik. Avrupa
\end{abstract} Bilim ve Teknoloji Dergisi, (21), 184-194.

\section{$\ddot{O} \mathbf{z}$}

Nörobilim (Sinirbilim), sinir sisteminin nasıl geliştiğini, yapısını ve ne yaptığını incelemekte olup matematik, dilbilim, mühendislik, kimya, felsefe, psikoloji ve tıp gibi diğer disiplinlerle yakın ilişki kuran disiplinler arası bir bilimdir. İşletme disiplininde nörobilimsel yaklaşım nöropazarlama ve nörogirişimcilik olarak yer almaktadır. Sosyo-ekonomik önemleri nedeniyle girişimcilik araştırmaları literatür zenginliğinin yanı sıra bulgularının uygulamaya aktarılması ile ülkelerin refah seviyelerinin arttrılmasında büyük önem taşımaktadır. Nörogirişimcilikgirişimci davranışlarını ve bu davranışlarla ilgili değişimleri anlamak ve analiz etmek için nörobilimsel yöntemlerin uygulanması oluparaştırmacılar ile nörobilim uzmanlarının bir araya gelerek multidisipliner bir yaklaşımla araştırmalar yürütmesi neticesinde nörogirişimcilik alanında önemli kazanımlar elde edilmiştir. Dopamin hormonu ile girişmcilik davranışı ilişkisi, girişimcilerin girişimci olmayan bireylere göre farklı zihinsel kaynakları ve sinirsel yapıları kullanmaları gibi literatür sonuçları girişimcilik disiplinine farklı bir boyut getirmektedir. Nörogirişimcilik literatürünün yeni oluşması bu çalışmanın kısıtını oluşturmakta olup konunun artan önemi ve nörobilimdeki farklı disiplinlerde yürütülen çalışmalar ile yakın gelecekte nörogirişimciiğe ilişkin yürütülen çalışmaların sayısında da önemli bir artış olacağı öngörülmektedir. Nörobilimde kullanılan görüntüleme ve diğer teknolojik araştırma imkânlarının hızla gelişmesi ve araştırmacılar için ulaşılabilir olması nörogirişimciliğin gelişme sürecini hızlandırmaktadır. Araştırmaları daha öncelerde başlayan ve bulguları pratik uygulamalarda çok fazla kabul gören nöropazarlama araştırmaları ile nöropazarlama araştırmalarında kullanılan teknolojiler nörogirişimciliğin gelişmesine zemin hazırlamaktadır. Bu çalışmada dünyada henüz emekleme döneminde olan nörogirşimcilik literatürüne bilgi ve bulguların derlenmesi yolu ile katkı sağlanması amaçlanmaktadır. Gelecekte yapılacak olan çalışmalar, duygusal, davranışsal, kültürel, hesaplamalı, sosyal sinirbilim, nöroinformatik ve sistem sinirbiliminin girdilerini hesaba katarak, özellikle girişimci karar almanın arkasındaki mekanizmalar ve genel olarak girişimcilik sürecinin bilişsel, motivasyonel, duyuşsal ve hormonal süreçlerin derin bir analizine imkân sağlayacaktır.

\section{A Different Dimension in Entrepreneurship with a Neuroscience Approach: Neuroentrepreneurship}

\begin{abstract}
Neuroscience is an interdisciplinary science that studies how the nervous system develops, structure and does what it does, and establishes close relationships with other disciplines such as mathematics, linguistics, engineering, chemistry, philosophy, psychology, and medicine.In the business discipline, neuroscientific approach takes place as neuromarketing and neuroentrepreneurship. Due to their socio-economic importance, entrepreneurship researches are of great importance in increasing the welfare of countries by putting their findings into practice as well as the richness of the literature.Neuro-entrepreneurship is the application of neuroscientific methods to understand and analyze entrepreneurial behavior and the changes associated with these behaviors.Significant gains have been achieved in the field of neuro-entrepreneurship as a result of conducting research with a multidisciplinary approach by gathering
\end{abstract}


researchers and neuroscientists. The literature results such as the relationship between dopamine hormone and entrepreneurial behavior, the use of different mental resources and neural structures by entrepreneurs compared to non-entrepreneurs bring a different dimension to the entrepreneurship discipline.The new formation of neuroentrepreneurship literature is the limitation of this study. With the increasing importance of the subject and studies carried out in different disciplines in neuroscience, it is predicted that there will be a significant increase in the number of studies on neuro-entrepreneurship in the near future. The rapid development of scanning and other technological research facilities used in neuroscience and their availability for researchers accelerates the development process of neuroscience.Neuromarketing researches, whose researches have started earlier and whose findings are widely accepted in practical applications, and technologies used in neuromarketing researches lay the groundwork for the development of neuroentrepreneurship dicipline.In this study, it is aimed to contribute to neuroentrepreneurship literature, which is still in its infancy in the world, by compiling information and findings.Future studies will allow for a deep analysis of the cognitive, motivational, affective and hormonal processes of the entrepreneurial process in general and the mechanisms behind entrepreneurial decision-making in particular, taking into account the inputs of emotional, behavioral, cultural, computational, social neuroscience, neuroinformatics and systems neuroscience.

Keywords: Neuroscience, Neuroentrepreneurship, Neuromarketing

\section{Giriş}

Nörobilim (Sinirbilim), sinir sisteminin nasıl geliştiğini, yapısını ve ne yaptığını incelemekte olup matematik, dilbilim, mühendislik (bilgisayar, elektronik vb.) kimya, felsefe, psikoloji ve tıp gibi diğer disiplinlerle yakın ilişki kuran disiplinler arası bir bilimdir (Nordqvist, 2014). Nörobilim alanında bireylerin düşünce, duygu ve davranışları ile ilgili nörolojik süreçler, neden sonuç ilişkileri bağlamında yapılan çalışmalarla incelenmektedir. Ancak duygu analizi oldukça zor bir alandır. Bunun en temel nedeni ise birçok farklı duygunun aynı anda var olabilmesi ve yüz mimikleri açısından birbirlerine çok benzeyen duyguların bulunmasıdır (Arı̆̆ ve Turan, 2020). Bilişsel nörobilim, akıl yürütme, duygu, bellek, karar verme ve benzeri gibi düşünceler ardındaki sinirsel mekanizmaları anlamaya (Custodio, 2010: 12),nörobilimsel yöntem/araçlar, beynin yapısı ve işlevini açıklamaya çalışmaktadır. Teknolojik gelişmeler sayesinde biyolojik bilimlerin en hızlı büyüyen alanlarından biri haline gelen nörobilim, sosyal bilimlerde iktisat sosyoloji ve psikoloji gibi farklı disiplinlerde büyük çığır açan bir güç haline gelmiştir (McMullen vd., 2014). Nörobilim tıp başta olmak üzere matematik, kimya, mühendislik, sosyal bilimler, dilbilim, felsefe ve psikoloji gibi birçok farklı bilim dalı ile ilişki içerisindedir. İşletme disiplininde nörobilimsel yaklaşım nöropazarlama ve nörogirişimcilik olarak yer almaktadır. Nöropazarlama içerisinde hedef kitlenin anlaşılması amacıyla farklı yöntemlerle ve uyaran etkisiyle vücut tepkilerinin ölçülerek hedef kitlenin davranışlarını anlama, hedef kitlenin talep ettiği pazarlama iletişimini sağlama ve nihayetinde işletme amaçları doğrultusunda yönlendirme bulunmaktadır. Nöropazarlama konusu uzun yillardır araştırılmakta ve elde edilen yöntem ve bulgular özel sektörde aktif olarak kullanılmaktadır. Tüketici davranışları ile nörobilim arasında köprü kuran nöropazarlama, 2002'de ilk ortaya çıktığında tartışmalıyken güvenilirliği ve uygulama alanındaki etkinliği ilepazarlama profesyonelleri tarafından benimsenmiştir ve alan çok hızlı gelişmektedir (Morin, 2011, s. 131).Pratik uygulamaları o kadar kabul görmüştür ki Türkiyede yürütlen bir araştırmada nörologların ve pazarlama profesyonellerinin nöropazarlamayı pazarlama akademisyenlerine göre daha olumlu algıladıklarını ortaya koymaktadır.(Eser vd., 2011, s. 854).

Nörogirişimcilik girişimci davranışlarını ve bu davranışlarla ilgili değişimleri analiz etmek ve anlamak için nörobilimsel yöntemlerin uygulanması olarak tanımlanmaktadır (Miljkovic ve Alcakovic, 2010: 274).Nörogörüntüleme ve diğer sinirbilim yöntem ve araçlarıyla sinirbilimin farklı alt dallarından yararlanarak, girişimci zihniyet, düşünce (fikir), karar ve davranışlarının arkasındaki bilişsel, davranışsal, psikolojik, fizyolojik, biyolojik, duygusal, nörolojik, sosyolojik ve kültürel etkenlerin anlaşılması için yapılan bilimsel çalışmaların bir bütünü olan nörogirişimcilik konusu uluslararası literatürde çok yeni bir kavramdır. Nörogirişimcilik kavramının ele alındığı bu derleme çalışmada öncelikle nörogirişimcilik kavramı ve boyutları ele alınacak, girişimcilik davranışı içerisinde nörogirişimcilik ilişkisi irdelenecek sonrasında dünyada nörogirişimciliğe yönelik yürütülen çalışmalar değerlendirilerek tartışılacak ve önerilerde bulunulacaktır. Nörogirişimcilik literatürünün yeni oluşması bu çalışmanın kısıtını oluşturmakta olup konunun artan önemi karşısında yakın gelecekte nörogirişimciiğe ilişkin yürütülen çalışmaların sayısında da önemli bir artış olacağı öngörülmektedir. Gelecekte yapılacak olan çalışmalar, duygusal, davranışsal, kültürel, hesaplamalı, sosyal sinirbilim, nöroinformatik ve sistem sinirbiliminin girdilerini hesaba katarak, özellikle girişimci karar almanın arkasındaki mekanizmalar ve genel olarak girişimcilik sürecinin bilişsel, motivasyonel, duyuşsal ve hormonal süreçlerin derin bir analizine imkân sağlayacaktır.

\section{Nörogirişimciliğin Kavram ve Boyutları}

Gelişen teknolojiler sayesinde, insan bilincinde meydana gelen farklılık, değişiklik ve algıların görsel hale getirilerek kişilerin nasıl düşündüğü, nasıl karar verdiği, dili ve sembolleri nasıl kullandığı, elde ettiği bilgileri nasıl yorumladığı ve depoladığı, daha sonra elde edilen bilgi ve tecrübeleri nasıl kullandığının anlaşılması mümkündür (Baron, 1998: 275 278).Araştırmacılar, girişimcilerin nasıl düşündüğünü, davrandığını ve karar verdiklerini daha iyi anlamak ve test etmek için nörobilim, nöropsikoloji ve nöroekonomi alanlarındaki çalışmalardan faydalanmaktadır (Blair, 2010). Sinirbilimsel yaklaşım ile herhangi bir girişimcilik temasının araştırılması, iyi tasarlanmış bir deneyin detaylandırılmasına dayanmaktadır. Bunun yanı sıra teknolojik bileşenler de aynı oranda öneme sahiptir. Belirli bir girişimcilik araştırması sorusunu ele almak için nörobilimsel tekniklerin ve yöntemlerin başarılı bir şekilde uygulanması, aslında iyi tasarlanmış bir deneydir(Patel ve Fiet, 2010). Bu yaklaşım nörogirişimcilik (Krueger ve Welpe, 2014), girişimci sinirbilim (Mitchell vd., 2014) ve daha yakın zamanda ise beyin odaklı girişimcilik araştırması (Perez, 2017) olarak adlandırılmıştır. Bazı bilim adamlarına göre isenörogirişimcilik girişimcilerin nasıl düşündüklerini, nasıl davrandıklarını ve kararları nasıl aldıklarını daha iyi anlamak ve test etmek için nörobilim, nöropsikoloji ve nöroekonomi alanlarındaki 
çalışmalardan bilgileri ödünç alınmış yeni bir alan olarak tanımlamaktadır (Blair, 2010). Nörogirişimcilik deneysel girişimcilikten farklıdır, çünkü bu yaklaşım girişimci davranışlarını, ekonomi, bilişsel, sosyal, gelişimsel psikoloji, sinirbilim, felsefe ve evrimsel antropoloji perspektiflerinden araştırmaktadır. (Krueger ve Welpe, 2008). Bilişsel sinirbilimin girişimcilik çalışmalarıyla birlikte, bilişsel sinirbilim araç ve tekniklerinin kullanılmasıyla girişimcilik davranışının incelenmesi "nörogirişimcilik" olarak ifade edilmektedir (Krueger, 2011).Nörobilim yöntem/araç/tekniklerinin girişimcilik araştırmalarında kullanılması ile girişimci zihniyet/ davranış/düşünce /hareket/karar verme konularında mevcut bilgilerin sınanarak, yeni bilgi ve yaklaşımların ortaya çıkmasında etkili bir bilim alanı olan nörogirişimciliği Krueger ve Welpe (2014), girişimcilik alanındaki deneysel araştırmaların nörobilimle kesişmesi olarak nitelendirmektedir(Şekil 1).

\section{Şekil 1. Nörogirișimcilik ve deneysel girișimcilik alanları}

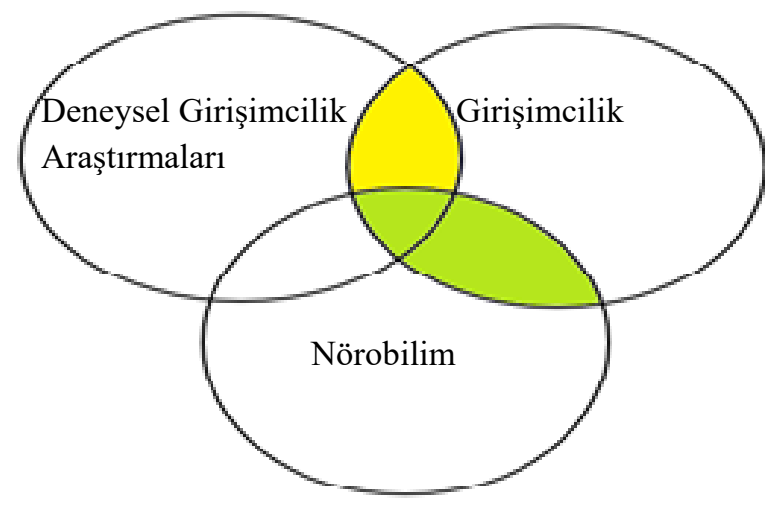

Deneysel girişimcilik alanları

Nörogirişimcilik

Kaynak: Krueger ve Welpe, (2014)

Nörogirişimcilik alanının nihai amacı, davranış başarı gibi girişimcilik unsurlarını belirleyen psikolojik ve biyolojik faktörlerin anlaşılması olduğundan, girişimcilik araştırmacıları ve iş bilim insanları, psikofizyolojik indeksleri keşfederek müthiş iç görüler elde edebilecektir (Colosio vd., 2017). Nörogirişimcilik kavramı literatürde ilk olarak 2006 yılından itibaren kullanılmaya başlanmıştır. Literatürde İngilizce kaynaklarda kullanıldığı anlaşılmakla birlikte, ilk yıllarda fazla ilgi görmediği ancak yıllar içerisinde giderek arttığı özellikle 2012 yılından itibaren alanda birçok çalışmanın yapıldığı anlaşılmaktadır. Bu rakam 2019 yılına gelindiğinde tepe noktasına ulaşmıştır. Bunun en önemli nedeni girişimcilik araştırmacılarının geçmiş teorik yaklaşımlardan bilimsel verilere dayanan nörobilim araçlarını kullanmaya başlaması olarak gösterilmektedir. Nörögirişimciliğin ortaya çıkışı ve yıllar içerinde giderek kullanımının yaygınlaşmasına dair bilgiler grafik 1'de verilmiştir.

Grafik 1. Yıllara göre nörogirişimcilik kavramının kullanımı (2019)

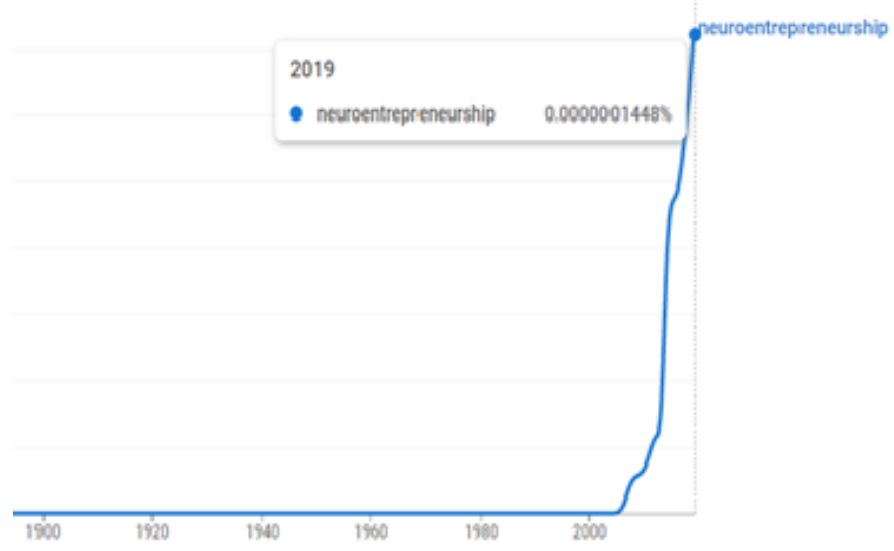

Kaynak:(Ngrams, 2020)

Girişimcilikle ilgili nörobilim alt dalları; bilişsel sinirbilim, duygusal sinirbilim, davranışsal sinirbilim, kültürel sinirbilim, hesaplamalı sinirbilim, nöroinformatik, sistem sinirbilimi ve sosyal sinirbilim olarak sıralanabilecektir. Bilişsel sinirbilim, insanlarda var olan yüksek bilişsel işlevleri ve bunların altında yatan sinir temellerini incelemektedir. Duygusal sinirbilim, nöronların duygularla ilişkili olarak nasıl davrandıklarını ve nasıl hareket ettiklerini ele almaktadır. Davranışsal sinirbilim, davranışın biyolojik temellerini incelerken, kültürel sinirbilim, inançların, uygulamaların ve kültürel değerlerin beyin, zihin ve genler tarafından farklı dönemlerde nasıl şekillendirildiğini araştırmaktadır. Hesaplamalı sinirbilim, beyin işlevini simüle etmek ve modellemek için bilgisayarları kullanarak beynin nasıl hesapladığını anlamaya çalışacak model ve öneriler sunmaktadır. Nöroinformatik, beyni anlamaya ve hastalıkları tedavi etmeye yardımcı olmak için sinirbilimin tüm alanlarındaki verileri entegre etmektedir. Nöroinformatik veri edinmeyi, bilgiyi paylaşmayı, yayınlamayı ve depolamayı, analiz, modelleme ve simülasyonu içermektedir. Sistem sinirbilimi, beyinde devam eden işlem türlerini tanımlamak için merkezi sinir sistemi içindeki veri akışı yollarını takip eder ve bu bilgiyi davranışsal işlevleri açıklamak için kullanmaktadır. Sosyal sinirbilim, biyolojik sistemlerin sosyal süreçleri ve davranışı nasıl uyguladığını anlamaya çalışan disiplinler arası bir alandır (Nordqvist, 2014). Girişimci zihniyet üzerine yapılan araştırmalar, girişimci eylemin dayandığı bilişsel ve duygusal temeller olduğunu ve bu temellerin bilinenden daha derinde olduğunu göstermektedir. Girişimci zihniyet, öğrenilmesi gereken bir dizi gerçek ya da öğretilecek bir dizi beceri değil, bir düşünme ve hissetme biçimidir. Girişimci zihniyeti gerçekten anlamak için nörobilimin zorlayıcı teori ve yöntemlerinden faydalanarak, daha derin bir perspektiften konuyu ele almak gereklidir.

\section{Girişimcilik Nörogirişimcilik \\ Davranışı} ve

İnsanlar doğası gereği meraklıdır ve bilim insan davranışlarının arkasındaki sebebi arama eğilimindedir. İnsanları girişimci olmaya yönlendiren sebep nedir? Yemek yemeye yönlendiren duygu açlık, su içmeye yönlendiren susuzluk ise girişimciliğe 
yönlendiren nedir? Girişimcilik faaliyetlerinin ortaya çıkmasında sosyal çevre, ekonomik çevre, politik düzen, kişisel geçmiş ve kişilik gibi birçok faktör etkileyici role sahiptir (Bird, 1988; Arenius and Minniti, 2005). Girişimcilik araştırmaları, firsatlar ve bireylerin etkileşimine yönelik kapsamlı deneyler yaparak, bu etkileşimi karşılaştırmanın ölçütlerini sağlıklı bir zeminde oluşturmalıdır. Her iki faktörün ortak araştırılması, Shane (2000, 2003) tarafından savunulan bireysel fırsat bağının araştırılması için kritik öneme sahiptir. Girişimcilik belirli kişilerin yalnızca sabit bir özelliği değildir bu nedenle firsatların varlığına gösterdikleri tepkiyi içermelidir (Shane, 2003). Ancak bugüne kadar, çok az araştırma bulmacanın her iki bölümünü de eşit bir şekilde bir araya getirmiştir. Girişimci karar verme süreçleri ile ilgili farklı teoriler ortaya atılmıştır. Ancak bu teorilerin birçoğu bireyin kişisel özellikleri ve dış faktörler üzerine odaklanmıştır. Alınan girişimcilik kararlarının merkezinde algılanan fırsat karşımıza çıkmaktadır. Fırsat/fırsatların algılanması girişimci niyetin belirgin hale gelmesini sağlayarak, bireyin harekete geçmesine neden olmaktadır. Girişimsel karar verme ve girişimci davranış modelinin en yaygın örneği şekil 2'de yer almaktadır.

\section{Şekil 2. Girişimci Fırsat Algısı ve Girişimci Davranış}

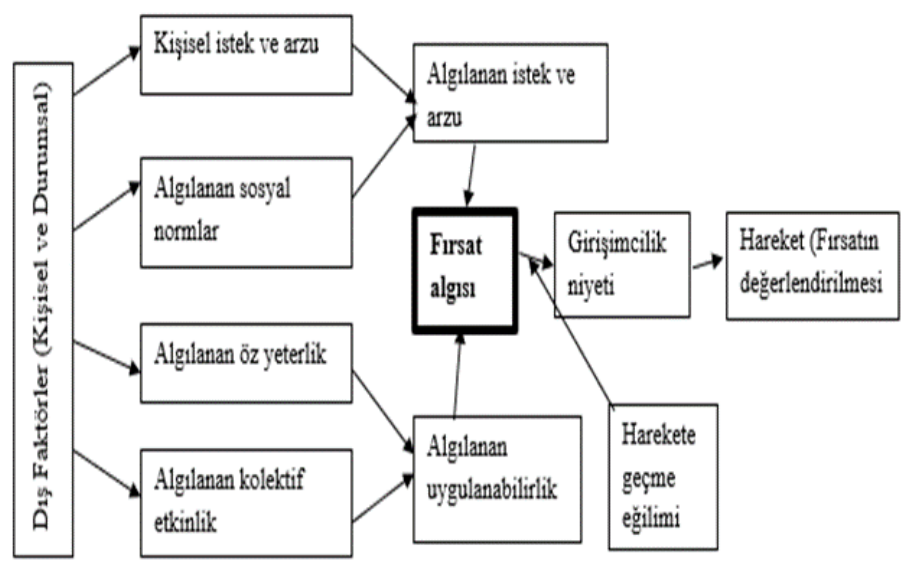

Kaynak: Krueger ve Brazeal, 1994; Krueger, 2000; Krueger vd., 2000; Shapero, 1985

Girişimcilik araştırmaları içerisinde en belirleyici olan girişimcilik niyetidir (Ajzen 2005; Krueger vd. 2000). Girişimcilik niyeti, rasyonel/analitik ve sezgisel/bütünsel düşünce (vizyon) içeren zihinsel bir süreçtir ve bu zihinsel süreç iş planının oluşturulması, firsat analizleri yapılması diğer amaç odaklı davranışları yönlendirmektedir (Boyd ve Vozikis, 1994, s. 63). Girişimcilik literatüründegirişimci olay modeli, girişimci niyet modeli ve planlı davranış teorisi olmak üzere girişimcilik niyetini açıklamaya çalışan üç önemli teori bulunmaktadır (Şeşen ve Basım, 2012, s. 22). Shapero ve Sokol'un (1982), girişimci olay modelinde girişimcilik, sosyal değişkenlerin (etnik gruplar gibi) gruplandırılması ve sosyo kültürel çevre tarafından şekillendirilmesidir. Girişimcilik olayı, inisiyatif alma, kaynakların konsolidasyonu, yönetim, göreceli özerklik ve risk alma ile ifade edilir. Girişimcilik niyeti algılardan ibarettir ve girişimcilik niyeti kişilerin arzu edilme algılarına, fizibilite algılarına ve harekete geçme eğilimine bağlıdır (Shapero ve Sokol, 1982). Bird (1988), girişimcilik niyetini girişimci niyet modeli ile açıklamıştır. Bird'e göre niyet kişinin dikkatini başarıya ulaşmak için özel bir amaç ya da yola yönlendiren bir zihin halidir. Niyet süreci girişimcinin kişisel ihtiyaçları, değerleri, istekleri, alışkanlıkları, inançları ile başlamaktadır. Bu beş unsur zamansal gerilim, stratejik odaklanma ve duruş olmak üzere 3 zihinsel (intrapsişik) niyetsel ve davranışsal çıktıyı sağlamaktadır (Bird., 1988, s. 445).Girişimcilik niyetini açıklayan teorilerin üçüncüsü ve en sık kullanılanı Ajzen'nin (1991) planlı davranış teorisidir. Yeni işletmeler zamanla ortaya çıkıp önemli planlamalar gerektirdiğinden girişimcilik bir planlı davranış türü olarak görülmektedir (KruegerJR vd., 2000, s. 410). Planlı Davranış Teorisi (TPB), bir bireyin belirli bir zaman ve yerde bir davranışta bulunma niyetini tahmin etmek için 1980'de gerekçeli eylem teorisi olarak başlamış, insanların kendi kendini kontrol etme yeteneğine sahip olduğu tüm davranışları açıklamayı amaçlamıştır (Wayne, 2019). Planlı davranış teorisinde girişimcilik niyetinin çıkış noktası olarak kişisel tutum, öznel norm ve algılanan davranış kontrolü olmak üzere üç unsur bulunmaktadır. Genel bir kural olarak, bir davranışla ilgili olarak tutum ve öznel norm ne kadar olumlu olursa ve algilanan davranışsal kontrol ne kadar büyükse, bireyin söz konusu davranışı gerçekleştirme niyeti o kadar güçlü olacaktır (Ajzen I., 1991, s. 188). Girişimcilik niyetine ilişkin teoriler niyetin farklı değişkenlerin etkisinde zihinsel bir süreç olduğuna vurgu yapmaktadır. Zihinsel bir süreç olan girişimcilik niyetini daha iyi anlamanın yolu insan beyninin daha iyi anlaşılması ile doğru orantılıdır ve günümüzün gelişmiş tıbbi araçlarının sayesinde insan beyninin, hormonların girişimcilik unsurlarıyla ilişkilendirilmesi ile girişimcilik araştırmaları yeni ve çok displinli bir boyut kazanmış bu boyut nörogirişimcilik olarak adlandırılmıştır.

\section{Şekil 3. Nörogirişimcilik}

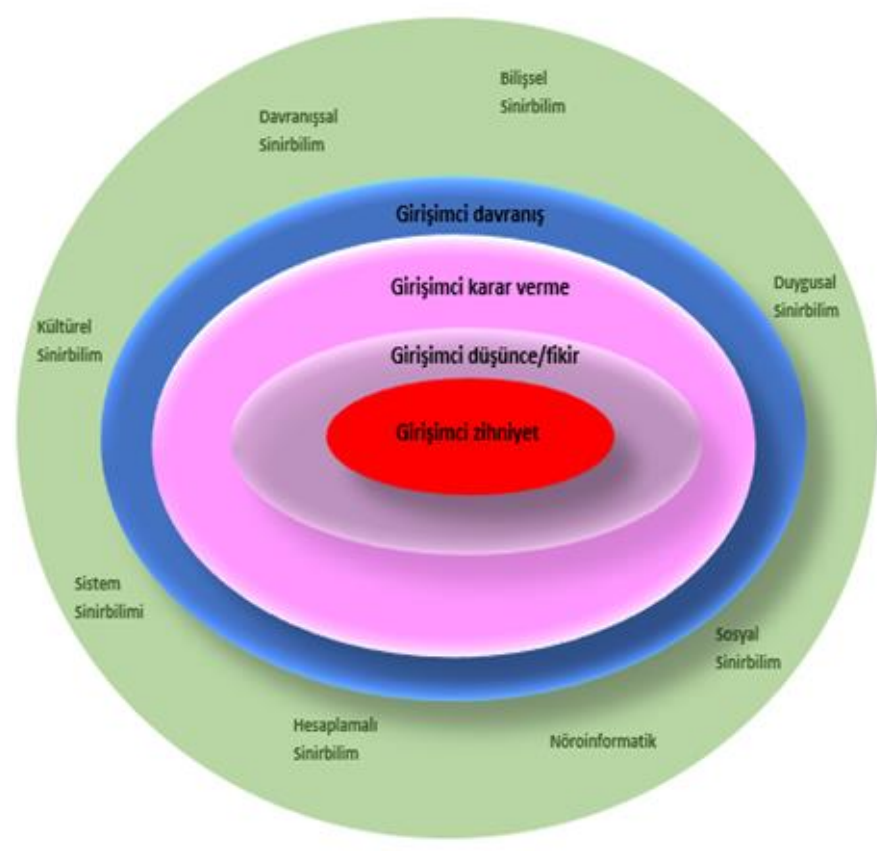


Kaynak: Yazarlar

Girişimcilik araştırmalarında alışılagelmiş uygulamalarda sınırlı sayıdaki örneklem grubunun ifadeleri ve davranışları dikkate alınmakta örneklem grubunun ifadeleri üzerinden yapılan tartışmalar literatüre taşınmaktadır. Burada en önemli kısıtların başında kasıtlı olarak veya anketörün baskısı, anket uygulanan kişinin anlık psikolojisi gibi farklı değişkenlerin etkisinde gerçek duygu ve düşüncelerin ifade edilip edilmediği gelmektedir. Bilimsel araştırma içerisindeki sebep sorgulamasının sonucu en son beyinsel süreçler noktasına kadar gelebilmektedir. $\mathrm{Bu}$ noktadan sonra nörobilimsel çalışmalarla karar sürecinin kaynağına ulaşma ihtiyacı doğmaktadır. Sinirbilimsel metodoloji, girişimcilik teorisi ve uygulamalarındaki kısıtlamaların üstesinden gelmek için potansiyel bir araçtır. Özellikle girişim öncesi karar süreçleri, bilişsel ve duyuşsal süreçleri araştırmak ve bazı metodolojik eksiklikleri gidermek için uygun olasılıklar dizisi sunmaktadır. Son yıllarda girişimcilik üzerine yapılan araştırmaların artması nörobilime olan ilgiyi de artırmıştır (Baron, 2006). Örneğin, beynin farklı bölümlerinde rasyonel ve duyuşsal bilişlerin gerçekleştiğine dair nörobilimsel kanıtlar düşünüldüğünde, nörobilimin beynin içerisinde gerçekleşen olaylar ve birbirleriyle olan ilişki ve farklılıkları ortaya koyma konusunda başarılı olduğu anlaşılmaktadır. Girişimcilik bağlamında yapılan çalışmaların odağında yer alan firsat kavramı ve firsatların girişimciler tarafından nasıl algılandığına dair yaklaşım biçimlerinin anlaşılması oldukça önemlidir. Bu nedenle nörobilimin, gerçek zamanlı firsat algısı ve öncüllerinin belirgin nörolojik belirteçlerini titizlikle tanımlanması gerekmektedir (Cacioppo vd., 1985; Camerer ve Fehr 2006). Çünkü girişimcileri diğer bireylerden ayıran en önemli spesifik özelliklerden biri fırsatları görme ve değerlendirme davranışıdır. Bu davranışın arkasında bulunan özelliklerin nörobilimsel olarak ortaya konulması girişimci davranış biçimlerinin nedenlerinin ve etkilerinin tam olarak anlaşılmasını sağlayacaktır. Girişimciler ve girişimcilik alanında yapılacak olan çalışmalar sayesinde, girişimciliğin gelişmesi bağlamında yapılması gerekenlerle ilgili önemli kazanımlar elde edilebilecektir.

Girişimcileri, sinirbilimciler bakımından ilgi çekici hale getiren etken, belirsiz ve karmaşık ortamlarda (Peelen ve Kastner 2014) firsatları nasıl belirledikleridir. Girişimcilik firsatlarının algılanması ve olumlu değerlendirilmesi, herhangi bir girişimcilik faaliyetinin önkoşuludur, bu nedenle bugüne kadar yapılan çoğu girişimcilik araştırmasının, bir girişimcilik firsatından yararlanma kararının alınmasından sonraki süreci ele alması ile ilgilidir (Shane, 2000). Kısacası asıl önemli olan bu kararın alınması süreci ve bu sürecin bileşenlerinin doğru anlaşılmasıdır. Çünkü firsatın değerlendirilmesi bu sürecin ve bileşenlerinin bir sonucudur. Potansiyel girişimcilerin firsatları değerlendirme süreci öncesi veya girişim öncesi karar süreçleri hakkında yeterince bilgi bulunmamaktadır. Bu nedenle çalışmaların çoğu, girişimci olarak hareket etme kararının öncüllerine bakmamış, ancak zaten girişimci olmaya karar vermiş bireyleri araştırmaya odaklanmıştır. Girişimcilik firsatlarından yararlanmak için gerçek kararı inceleyen araştırmalar, mevcut girişimcilik anlayışını e-ISSN: 2148-2683 büyük ölçüde geliştirecektir. Karar öncesi süreçleri deneysel yöntemlerle incelemek, yüzeysel olarak ele alınan konuların daha derinlemesine incelenmesine olanak sağlayacak ve olumlu katkılar sunacaktır. Girişim öncesi karar süreçlerinin daha iyi anlaşılması, akademisyenler tarafindan ileri sürülen kavramsal teorilerin kabul veya reddedilmesi bakımından önemli rol oynayacaktır. Örneğin, Shane (2003), girişimciliğin, katılımcılar tarafindan piyasada standart kaynakları alıp satmak için kullandıklarından niteliksel olarak farklı bir karar verme süreci kullandığını savunmakla birlikte bu teorik açıklama henüz test edilmemiş ve bu nedenle ampirikaraştırma tarafından desteklenmemektedir. Şu anda, girişimcilik akademisyenleri, girişimcilerin kullandığı yargısal karar verme süreçlerinin yalnızca teorik açıklamalarını sunmaktadır (Sarasvathy vd., 1998). Ardichvili vd. (2003), son yıllarda bilişsel psikoloji başta olmak üzere bir dizi disiplinden ödünç alınan çelişkili varsayımlara dayanarak girişimcilik öncesi süreçle ilgili bir dizi kavramsal modelin önerildiğini belirtmektedir.

Girişimci biliş, “insanların firsat değerlendirme, girişimleri oluşturma ve büyümeyi içeren değerlendirme, yarg1 veya kararlar verme için kullandıkları bilgi yapıları"nı ifade etmektedir (Mitchell vd., 2002: 97). Girişimci biliş, girişimcilerin girişimci davranış ve düşünceden sorumlu zihinsel mekanizmalarının ve yapılarının gelişimini açıklamak için yararlı olan bilişsel psikoloji ve sosyal biliş literatüründen teoriler, deneysel kanıtlar ve kavramları ödünç almaktadır (Santos vd., 2016). Girişimci biliş üzerine araştırmalar son dönemde artmakla birlikte (Tumasjan vd., 2012), mevcut araştırmalar, "girişimcilik firsatlarını algılayan, değerlendiren ve kullanan kim" sorusunun henüz tam olarak yanıtlayamamaktadır (Shane, 2003). Öncü girişimcilerde derin bilișsel süreçlerin incelenmesi araştırmalarının öncüsü olan yazarlar (Mitchell ve Chesteen 1995; Mitchell vd. 2007) girişimci bilişi, insanların fırsat değerlendirme, girişim yaratma, büyümeyi içeren değerlendirme, yargı ve kararlar vermek için kullandıkları bilgi yapıları olarak tanımlamaktadır. Mitchell vd. (2007), firsatların keşfedilip keşfedilmeyeceğini ve kullanılıp kullanılmayacağını belirleyen şeyin esas olarak bilgi farklılıkları olduğunu ileri sürmektedir. Girişimci biliş araştırması bakımından, yaklaşan firsatları öngörerek, duygular ve etkilerin yanı sıra, daha ileri analizler için girişimci eylemlerinin araştırılması gerektiği ifade edilmektedir. Girişimci biliş araştırmalarında önemli bir soru, girişimcilerin bilgiyle nasıl başa çıktığıdır. Girişimcilik sürecinin anlaşılmasında firsat keşfini açıklamanın önemi düşünüldüğünde, keşif sürecini destekleyen veya çürüten ampirik kanıtlar önemlidir (Shane, 2000).

Simon (1963), bilişsel karar verme sürecinin birbiriyle ilişkili üç süreçten meydana geldiğini iddia etmiştir. Bunlar semantik, sembolik ve nörolojik bileşenlerdir. Semantik, bireyin ne söylediği ve ne yaptığı, sembolik, bireyin sahip olduğu tutum, inanç ve niyetler, nörolojik ise tüm bunların biyolojik olarak işlenmesi ile birlikte karar verme eyleminin gerçekleşmesidir. Girişimcilikle ilgili bilişsel olaylar, Simon'un üç seviyesinde nasıl birbiriyle ilişkili olduğuna dair yapılacak olan deneysel yaklaşımlarla daha iyi anlaşılacaktır. Örneğin, fırsat algısının 188 
altında yatan "sembolik" düzey yapıları ile "anlamsal" düzey ipuçlarının hangi düzeyde ilişkili olduğunun anlaşılması, girişimci düşünce yapısının tam olarak anlaşılması bakımından büyük fayda sağlayacaktır.

Wood ve Williams (2014), girişimcilerin bir durumu yargılamak için kullandıkları kriterlerin fursat, yenilik, kaynak verimliliği ve en kötü durum senaryosu olduğunu öne sürmüştür. Bir girişimcinin bir fikir üzerine hareket edip etmemeyi seçmesi için, başarılı sonuçlara güçlü bir şekilde inanması, belirgin olsa bile bazen uyumsuz unsurları görmezden gelerek, en azından kolayca temin edebileceği bilgileri elde etmesi gerekmektedir. $\mathrm{Bu}$ tür bir akıl yürütme, normatif/rasyonel düşünme modelini takip etmediği için olağan ihtiyatlı yaklaşımın tersi olarak kabul edilmektedir (Mitchell vd., 2007). Nitekim, son araştırmalar, yüksek belirsizlik bağlamında karar vermenin, beynin ön kısmında bulunan dorsolateral prefrontal korteksi içeren karmaşık bir sinir ağı sistemini kullandığını göstermiştir (Ernst ve Steinhauser, 2015).

McMullen vd., (2014), girişimcilerin firsat belirleme sistemlerini ve zihinsel teorilerini nasıl oluşturduklarını iki boyutlu olarak dört ana paradigma altında belirlemiştir (Şekil 4). Birinci boyut, firsatların dışsal veya içsel olarak tanımlanmasıdır (firsat inançlarının oluşumu ve başarılı bir şekilde uygulanmasının öncelikle bireyin içsel veya dişsal bir uyaran tarafindan tetiklenip tetiklenmediğinin bilinmesi). İkinci boyut ise farklılıkların yarattığı kalıcı veya geçici olaylardır. Bu iki boyut dört paradigma altında incelenmektedir. Bunlardan ilki kişilik özellikleri ve hatta genetik gibi kalıcı iç tutumu destekleyen özellik açıklamaları (Nicolaou ve Shane, 2014); ikincisi adaptasyon açıklamaları, bilişsel temelli yaklaşımları yeniden gruplandıran ve kişinin girişimci olarak doğmadığı, daha çok olumlu bilişsel yatkınlıklar sayesinde girişimci davranışları benimsediği fikri; üçüncüsü bilginin rolüne, günlük öğrenmeye ve herhangi bir yatkınlık üzerinde deneyime değer veren uzmanlık açıklamaları; ve dördüncü paradigma ise girişimcilerin benzersiz bir düşünce yapısına sahip olduğunu açıklayan zihniyet yaklaşımlarıdır.

Şekil 4. Firsat Belirleme ve Zihin Teorileri

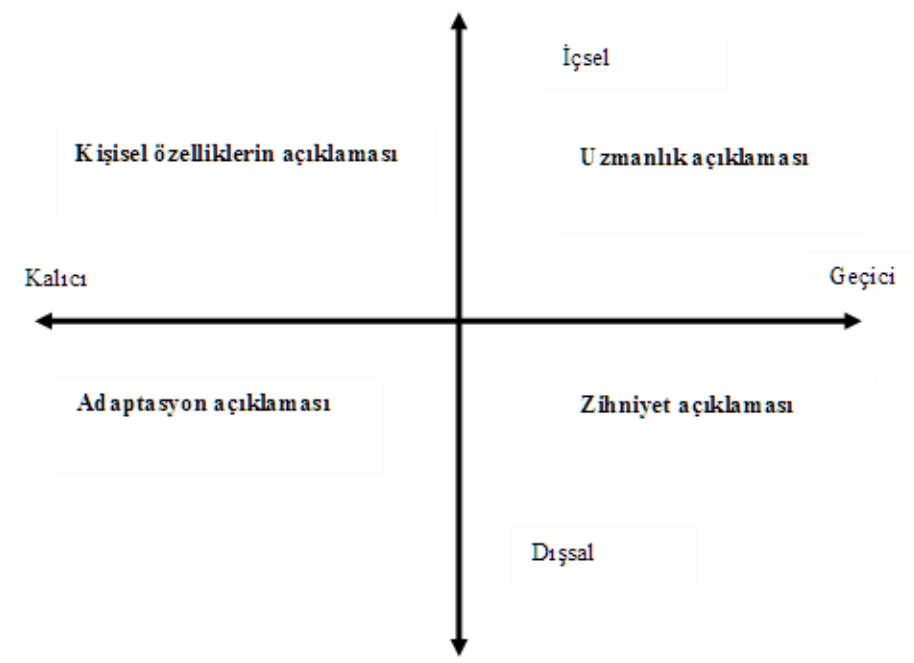

Kaynak: McMullen vd., (2014)

Girişimcilik firsatlarının algılanması ve olumlu değerlendirilmesi, herhangi bir girişimcilik faaliyetinin önkoşuludur, bu nedenle bugüne kadarki çoğu girişimcilik araştırmasının, bir girişimcilik firsatından yararlanma kararının alınmasından sonra başlaması şaşırtıcıdır (Shane, 2000). Önemli olan firsatların nasıl algılandığı, girişimci davranış biçimi, firsat/ların değerlendirilmesi kararı, harekete geçme ve uygulamalar sonrası yaşanan gelişmelerle ilgili aydınlatılamayan kısımların açığa çıkarılmasıdır. Ancak sosyal bilimlerin sahip olduğu yöntem ve araçlar bu soruların cevabını verebilecek yeterliliğe sahip değildir. $\mathrm{Bu}$ nedenle nörobilim yöntem ve araçlarının sosyal bilimlere entegre (uyumlaştırılması) edilmesi ile birlikte bu soruların cevabını bulmak mümkün olacaktır. Girişimci davranış, karar ve algılarının nedenlerini inceleyen nörobilim alt dalları; bilişsel sinirbilim, duygusal sinirbilim, davranışsal sinirbilim, kültürel sinirbilim, hesaplamalı sinirbilim, nöroinformatik, sistem sinirbilimi ve sosyal sinirbilimdir. Her bir farklı nörobilim alt dalı, girişimci bireyleri fiziksel, duygusal, sosyolojik, psikolojik, davranışsal, bilişsel, zihinsel ve kültürel bakımdan incelemektedir. Girişimci düşüncenin anlaşılması girişimcilik niyeti, karar verme ve girişimci davranışın anlaşılmasına olanak sağlamaktadır.

Nörogirişimcilik alanında yapılan çalışmalar incelendiğinde, bunların bir kısmının nörogörüntüleme yöntem ve araçlarıyla yapıldığı, bir kısmının vücut kimyasalları ve hormonlar bağlamından ele alındığı ve bazılarının nörobilișsel yöntemlerle değerlendirilmeye çalışıldığı görülmektedir. $\mathrm{Bu}$ kapsamda yapılan çalışmalardan biri Lawrence vd., (2008), tarafından yapılan, girişimciler ve yöneticilerin karar verme süreçleri bakımından karşılaştırılmasına dayanan yapmış oldukları nörobilişsel çalışmadır. Çalışmada, duygusal ve riskli kararların alındığı beyin kısmı "sıcak biliş" olarak, akılcı ve duygusal olmayan kararların alındığı bölge ise "soğuk biliş" olarak ifade edilmiştir. İşletmeye personel alımı gibi düşük risk düzeyi gerektiren kararların alınmasında girişimciler ve yöneticiler benzer özellikler gösterirken her iki araştırma grubunun da soğuk biliş olarak adlandırılan kısmı kullandıkları anlaşılmaktadır. Ancak sıcak bilişle ilgili riskli karar verme süreçleri bakımından girişimciler yöneticilerden farklı davranış göstermişlerdir. Nitekim son araştırmalara göre, yüksek belirsizlik bağlamında karar verme sürecinde, beynin ön kısmında bulunan dorsolateral prefrontal korteksi içeren karmaşık bir sinir ağını kullanılmaktadır (Ernst ve Steinhauser, 2015). Her iki durumda da beynin görüntüleme yöntemleriyle gözlemlenmesi sayesinde (soğuk bilişsel süreç ve sıcak bilişsel süreç) soğuk bilişsel karar verme esnasında beyindeki dorsolateral prefrontal korteks olarak adlandırılan alanın, sıcak bilişsel karar verme durumunda ise orbital frontal kortekstin aktif olduğu görülmektedir. Çalışma neticesinde elde edilen önemli bulgulardan biri, girişimcilerin ve girişimci olmayan bireylerin karar verme süreçleri bakımından farklı nörolojik özelliklere sahip oldukları ve bu durumu karar verme esnasında kullandıkları yapılan nörogörüntüleme sonucunda anlaşılmıştır. Beyinde yer alan farklı sinirsel ağlar ve bölgeler, bireylerin karar verme süreçleri anında farklı hareket ettikleri ve bu sayede girişimci karar verme süreçleri ile ilgili önemli bilgilerin elde edilebileceği sonucuna varılmıştır. Gelecekte ise yapılacak olan araştırmalarda, beyinde yer alan farklı bölgeleri harekete geçirmek bakımından dışardan bir uyarıcı ile bunun yapılıp yapılamayacağının araştırılması gerekmektedir. 
Nörobilim teknik ve yöntemleriyle nörogirişimcilik alanında yapılan çalışmalardan biri de hormonlarla yapılan çalışmalardır. $\mathrm{Bu}$ çalışmaların en büyük özelliği, girişimci davranışı tahmin edebilen, belirleyebilen veya buna yol açabilen en bilinen kimyasalların (hormonların) neler olduğu ve bu kimyasalların, bir girişimcinin başarılı olup olmamasında belirleyici olan sinirsel ve biyolojik temellerin esaslarının neler olduğunun anlaşılmasına yardımcı olmasıdır. White vd., (2006), girişimciliği testosteron hormonu ve girişimcilikle ilişkilendirilebilecek davranışlar arasında ilişki kurarak açıklamaya çalışmıştır. Testosteron hormonu ile ilişkilendirilebilen birçok davranış girişimci davranışla paralellik göstermektedir. Çalışmada testosteron seviyesi yüksek olan bireyler korkusuz, 1srarlı, kendine güvenen, odaklanmış, bağımsız, eylem odaklı, hareketli, ben merkezli ve itaatkâr olmayan kişiler olarak tanımlanmaktadır. Bu benzerlik farklı araştırma sonuçlarıyla da desteklenmektedir. Benzer şekilde Guiso ve Rustichini (2011), doğum öncesi testosterona daha fazla maruz kalan girişimcilerin daha fazla çalışana, daha yüksek gelire sahip olduğunu ve daha hızlı büyüyen firmaları yönettiğini bulmuştur. Testosteron ve kortizol gibi hormonlar, insanların girişimci olma eğilimini etkilemektedir (Nicolaou vd., 2018; Wolfe ve Patel, 2017). Daha yüksek testosteron düzeyine sahip bireylerin girişimsel davranma olasılığı daha yüksektir. Coates ve Herbert (2007), yapmış oldukları çalışmada, T stres hormonları ve profesyonel hisse senedi tüccarlarının ticaret performansı arasındaki ilişkiyi incelemiştir. Sabah saatlerinde daha yüksek seviyede olan T'nin daha yüksek ortalama getiri ile ilişkili olduğunu ve kortizolün piyasa oynaklığıyla arttığını bulmuşlardır. Bireylerin herhangi bir durum karşısında korku duymaları halinde amigdala adı verilen bir hormon salgılanmaktadır. Benzer durumun herhangi bir girişimcinin belirsiz bir ortamda hareket ederek maddi kazanç elde etme ihtimalini bilmediği durumda da yaşandığ 1 ve bu hormonun salgılandığ veya tiksinme hissettiğinde ise insula adı verilen bir hormon salgılamakta olup benzer durum tıpkı kumar oynayan bir kişinin kazanma veya kaybetme olasılığını kestiremediği anda bu hormonun güçlü biçimde harekete geçmesiyle aynıdır (Singh ve Ronch, 2011: 96). Vücutta bulunan dopamin ise hareket, hafiza, dikkat, uyku ve duygu durum düzenleme gibi çeşitli işlevlerle bağlantılı bir nörotransmiterdir (sinir hücrelerindeki bilgi akışını sağlayan küçük kimyasal iletkenler). Dopamin, beyni "memnun ederek" ve "ödüllendirerek" davranışı güçlendirmede merkezi bir rol oynar, bu da bir eylemin sinirsel temsilinin pekişmesine ve bu eylemin bir zevk duygusuyla ilişkilendirilmesine yol açmaktadır (Berridge ve Kringelbach, 2008). Lawrence vd., (2008) ise dopamin adı verilen hormonun beyinde yer alan sicak ve soğuk bilişsel süreçlerde etkili olduğunu ifade etmiştir. Treadway vd., (2009), girişimcilerin daha fazla risk alma eğiliminde olduklarını ve bu nedenle girişimcilerin serebral kortekslerinde dopamin reseptörü sayısı ve yoğunluklarında değişikliklerin meydana geldiğini ortaya koymuştur. Treadway vd., (2012), dopamin hormonu seviyesi artışının ekonomik karar verme süreci üzerinde doğrudan bir etkisinin olduğu ve daha fazla kazanç veya kâr elde etme isteği ile dopamin seviyesinin artması arasında pozitif yönlü bir ilişki bulunduğunu belirtmiştir. Bu kapsamda nörotransmitter (sinir hücrelerindeki bilgi akışını sağlayan küçük kimyasal iletkenler) üzerine yapılacak olan çalışmalar girişimcilik hakkında önemli nörobiyolojik bilgiler elde edilmesine olanak sağlayacaktır. Ancak girişimcilik araştırmaları kapsamında henüz araştırma yapılmayan hormonlar, oksitosin ve serotonindir. Özellikle bu ve benzeri hormonların girişimcilik araştırmaları bakımından ele alınması gerekmektedir (Nofal vd., 2017).
Zaro vd., (2016), girişimci olan ve girişimci olmayan bireylerdenörogörüntüleme araçlarından biri olan EEG ile yapılan yapmış oldukları çalışmalarında, firsatları görme ve riskli karar verme süreçlerinde her iki grubun farklı sinirsel ağlar ve farklı nöral yapıları kullandıklarını tespit etmiştir. Özellikle girişimcilerin riskli finansal kararlar alırken belirli bir içeriğin tamamını veya belirli bir kısmını değerlendirdiği, girişimci olmayan kişilerin ise belirli bir risk alıp alamayacağı konusunda daha kişisel bir bağlam üzerine yoğunlaştığı görülmüştür. Bir diğer önemli farklılık ise girişimcilerin firsatları görme ve riskli kararlar alma konusunda beynin sağ ve sol frontal bölgelerinde bulunan bilişsel bölgelerden yararlanmalarıdır. Girişimcilerin fırsatları görme ve riskli kararlar alma süreçleri bakımından farklı nöral organizasyonları kullandıkları bilindiği için, nörogirişimcilik bağlamında yapılacak olan çalışmalar sayesinde girişimcilerin firsatları görme ve riskli karar verme süreçleri hakkında net ve somut bilgilere ulaşılabilecektir. $\mathrm{Bu}$ sayede sonradan girişimci olunup olunamayacağı veya girişimci bireyler yetiştirmek için hangi bilimsel yöntemlerin kullanılabileceği araştırılabilecektir.

Transkraniyal manyetik stimülasyon (TMS), insan beyninin invaziv olmayan uyarımına izin veren nörofizyolojik bir tekniktir. Bu teknik, beynin belirli bölgelerinin aktivitesini düzenlemek için manyetik indüksiyon adı verilen araçlar kullanmaktadır. Beyne bağlandığında, nöronları uyarmak ve nöral aktiviteyi takip etmek için elektriksel akım üretme yeteneği bulunan demir bir çekirdek yer almaktadır. TMS, dikkat, katılım, tanıma gibi davranış değişikliklerini ölçmede, belirli beyin bölgelerinin geçici olarak çevrimdışı duruma getirilmesinin nedensel rolünü incelemede kullanılmaktadır (Gani vd.,2015: 297). Carter vd., (2019), yaratıcılığın frontal lobda gerçekleştiğini iddia etmiş ve yapmış oldukları çalışmada TMS (Transkranial manyetik stimulasyon) adı verilen bir yöntemle (beyindeki nöronları uyaran noninvaziv bir yöntem), beynin gamma dalgalarıyla üretilen dikkatli düşünme sürecinde yaratıcılığının düşük olduğu ancak alfa dalgalarıyla üretilen beynin boş durma evresine geçtiğinde yaratıcılığının yüksek olduğunu ileri sürmüştür. $\mathrm{Bu}$ sayede girişimcilik anlamında yaratıcılığı artırılabilmenin mümkün olup olmayacağı araştırılabilecektir.

Erkek ve kadın girişimcilerdeki farklılıkları araştırmak için davranışsal genetik yaklaşımları kullanan Zhang vd., (2009), iki psikolojik özelliği değerlendirerek, cinsiyet farklılıklarının ve genetik katkının girişimci davranışlarda bulunma eğilimi üzerindeki etkisini araştırmış ve iki etken üzerinde durmuşlardır. Bunlar, dışa dönüklük ve nevrotiklik (önemli bir biyolojik temeli olan bir kişilik özelliği) olma özellikleridir. Çalışma kapsamında gerek tek yumurta gerekse çift yumurta ikizleri üzerinde yapılan araştırmalar, kadınların girişimci olma eğiliminin güçlü bir şekilde genetik temelli olduğunu ve büyük ölçüde hem dişa dönüklük hem de nevrotiklik tarafından belirlendiğini göstermiştir. Erkeklerde ise bu durum tam aksine, paylaşılan çevre ve dışadönüklüğün temel bir katkısı olduğunu iddia eden bir model önerisinde bulunmuşlardır.

Martinez vd. (2014) girişimciler ve yöneticiler arasında karar verme verimliliğinin arkasındaki nörobiyolojik mekanizmaları inceleyerek, karar verme verimliliğini, toplam getirinin yanıt süresine bölünmesiyle elde etmeye çalışmıştır. Hızlı karar alma yeteneğinin, değişen hızlı çevresel koşullara uyum sağlamada, işletmelerin varlığını sürdürmelerinde ve pazar koşullarında rekabet edebilme yetenekleri üzerinde önemli pay sahibi olduğunu ileri sürmüştür. Teran vd. (2014)ise, girişimci karar vermede nörofizyolojik ve kişilik özellikleri arasındaki ilişkiyi 
inceleyerek, karar vermenin kurucu girişimciler ve kurucu olmayan girişimciler arasında nasıl farklılaştığına odaklanmıştır. Kurucu girişimciler tüm süreçleri (fırsatların görülmesi, değerlendirilmesi, karar verilmesi, girişmcilik faaliyetlerinde bulunulması ve sonuçların gözden geçirilmesi) en başından itibaren göz önüne alarak karar verirler. Ancak kurucu olmayan girişimciler ise girişimcilik sürecinin belirli bir noktasından itibaren sürece dahil olurlar. Karar vermeyi kalite ve zaman açısından değerlendirirken, karar verme hızı olarak da bilinen tepki süresi ve arkasındaki bilişsel mekanizmaları ele almıştır. Çalışma sonucunda kurucu girişimcilerin, kurucu olmayan girişimcilere göre daha hızlı kararlar aldıkları tespit edilmiştir. Kurucu girişimciler fırsat tanımaya ve yakalamaya daha fazla yönelmiş olduğu için hangi firsatların peşinden gidecekleri konusunda daha hızlı kararlar verebilmektedir.Bununla birlikte, Barnea vd., (2010), çevrenin finansal durumlarda davranışı etkilediğini, aile ortamı ile genç yatırımcıların davranışları arasında önemli bir ilişki bulunduğunu ancak aile etkisinin belirli bir süre devam ettiğini ve zaman içerisinde bu etkinin yerini deneyime bıraktığını iddia etmiştir.Bireylerin girişimci olmaları bakımından doğup büyüdükleri aile, sosyal ve koşullar önemlidir. $\mathrm{Bu}$ durum bireyin girişimci olmasında çevresel faktörlerin daha etkili olduğunu düşündürmektedir. Ancak gelecekteki araştırmalar, genetik ve çevresel faktörlerin bireylerin girişimci olmaları bakımından detaylı olarak karşılaştırılmasına olanak sağlayacaktır. Örneğin, genetik ve deneyim, farklı yaşam aşamalarında davranışı farklı şekilde etkiler mi? Birbirlerini güçlendiriyorlar mı? Girişimciliğin önündeki kültürel engellerin bazı genetik etkiler nedeniyle aşılması mümkün müdür? Vb soruların cevabı bulunabilecektir.

Karar verme süreçleri ile ilgili yapılan diğer ilginç bir çalışmada, beynin farkındalığı yöneten kısmına bir karar girmeden on saniye öncesine kadar tespit edilebilir beyin aktiviteleri olduğunu göstermiştir. Gözlemlenen beyin elektrik modellerinin analizleri sayesinde araştırmacılar, katılımcıların seçmek üzere oldukları şeye erişmeden önce, iki farklı seçenek arasındaki kararın ne olabileceğini yüksek doğrulukla tahmin etmeyi başarmıştır (Soon vd., 2008). Bu çalışmanın bir varyasyonunun, girişimcilerin firsatların değerlendirilmesi sırasında nasıl karar verdiklerini ve kararlarına nasıl ulaştıklarını test etmek için kullanılabileceği varsayılmaktadır (Holan ve Couffe, 2017). Girişimcilerin beyinleri fizyolojik olarak diğer kişilerin beyinleriyle aynıdır, ancak deneyimler ve bilgi açısından farklıdır (Baucus vd., 2014). Holan vd., (2013), girişimcilerin ve girişimci olmayanların bir sorunu çözmek için farklı zihinsel kaynakları kullandıklarını, girişimcilerin uyarana hızlı tepki verirken ve çok fazla düşünmeden bir karar aldığııı ancak girişimci olmayanların ise karar vermeden önce sorunun bilişsel olarak detaylandırılmasına ihtiyaç duyduklarını belirtmiştir. Bu durum, beynin farklı alanlarının harekete geçirilmesi, iki grubun görevi tamamlamak için ihtiyaç duyduğu zamandaki farkı (girişimciler daha hızlıdır) girişimcileri girişimci olmayanlardan ayırmak için açıklamaya yardımcı olan "belirli bilişsel faktörlerin var olduğu" hipotezini de desteklemektedir (Hoskisson vd., 2011). Aynı şekilde, Gaglio ve Katz (2001), girişimcilerin firsatları tespit etmelerine ve harekete geçmelerine izin veren benzersiz bir algısal ve bilgi işleme becerilerine sahip oldukları hipotezine dayanan detaylı bir firsat tanımlama modeli önermektedir. $\mathrm{Bu}$ model, girişimcilerinuyanıklık veya tepki vermeye hazır olma durumuna dayanarak, piyasadaki dengesizlikleri fark etme konusunda oldukça başarılı olduklarını iddia ederekbu konunun nörogirişimcilik için bir araştırma programına çevrilebileceğini öne sürmüştür.

e-ISSN: 2148-2683

\section{Araştırma Sonuçları ve Tartışma}

İnsan hayatı üzerinde önemli etkiye sahip birçok farklı bilim dalında kullanılan nörobilim, bireylerin davranış biçimleri ve bunların arka planında yer alan nedenlerin açıklanması ve davranış biçimlerinin şekillendirilmesi bakımından yol gösterici özelliğe sahiptir. Bu nedenle girişimcilik alanında yapılan ve yapılacak olan çalışmalarda, girişimcilerin davranış biçimleri, kişilik özellikleri, girişimci tipolojilerinin analiz edilmesi, girişimcilerin ortak özellikleri ve davranış/yaklaşım biçimlerinin anlaşılması, girişimci karar verme süreçleri ve firsatların değerlendirilmesi ile ilgili girişimci tutumlarının anlaşılması, girişimci kişiliğin gelişimine etki eden faktörlerin belirlenmesi, girişimci eğitimlerinin nasıl olması gerektiği gibi daha birçok konuda nörobilim alanının önemli bir potansiyeli bulunmaktadır. Araştırmacılar ile nörobilim uzmanlarının bir araya gelerek multidisipliner bir yaklaşım benimsemesi neticesinde nörogirişimcilik alanında önemli kazanımlar elde edilmiştir. Elde edilen bilgiler sayesinde mevcut teori ve uygulamaların bir kısmının doğruluğu veya yanlışlığı teyit edilmeye başlanmıştır. Bu sayede yirmi birinci yüzyılın "girişimcilik anlayışı" geçmiş klasik girişimcilik anlayışından oldukça farklı bir noktaya doğru ilerlemektedir. Ülke ekonomilerinin dinamosu olan girişimciler üretmiş oldukları mal ve hizmetlerle yalnızca toplumsal refahın artmasına katkı sağlamakla kalmayıp aynı zamanda sosyal ve çevresel yönden de katkılar sağlamaktadır. $\mathrm{Bu}$ nedenle işletmelerin daha nitelikli hale gelmesi sadece işletmlerin kendi sorumlulukları olarak görülmemekte sosyo-ekonomik önemleri nedeniyle nitelikli girişimcilik konusu ülkeler için milli bir mesele haline gelmektedir. Bu sorumlulukla ülke yönetimleri tarafından uygulanan destek ve teşviklerle girişimciliğin güçlendirilmesi yeni yüzyılın en önemli politika araçlarındandır.

Nörogirişimciliğin, girişimcilik araştırma ve uygulamalarını ilerletmek için psikolojik mekanizmalar sağlama potansiyeline sahip olduğu bilinmektedir. Nörogirişimcilik alanında yapılan çalışma sayısının oldukça az olduğu görülmekle birlikte Horman, beyin, gen gibi konularda yapılan çalışmaların sonuçları nörogirişimliğin gelişme potansiyalinin oldukça fazla olduğunu göstermektedir. Gelecekte yapılacak olan çalışmalar, duygusal, davranışsal, kültürel, hesaplamalı, sosyal sinirbilim, nöroinformatik ve sistem sinirbiliminin girdilerini hesaba katarak, özellikle girişimci karar almanın arkasındaki mekanizmalar ve genel olarak girişimcilik sürecinin bilişsel, motivasyonel, duyuşsal ve hormonal süreçlerin derin bir analizine imkân sağlayacaktır. Bu sayede hormonal (Nicolaou ve Shane, 2014) ve genetik farklılıkların beynin kablolamasını, yapısını ve işlevini nasıl etkilediğine dair araştırmaları yapmak mümkün olacaktır (Toga ve Thompson, 2005)

Nörobilim teorisi ve metodolojisinin uygulanmasının, girişimciliğin geliştirilmesine nasıl yardımcı olabileceğini tartışmak için mevcut girişimcilik araştırmalarındaki kronik eksiklikleri, zorlukları ve gelişme potansiyellerini dikkate almak gerekmektedir. Bu ihtiyaç tespiti sonrası girişimcilik bağlamında elde edilen bilgilerin nörobilim yöntem, araç ve tekniklerine entegre edilerek, girişimciler veya potansiyel girişimciler üzerinde uygulanması sonrası literatüre kazandırılması hem nörobilimin gelişmesine hem girişimcilik literatürünün gelişmesine katkı sağlayacaktır. Bu noktada bir diğer önemli unsur olarak nörogirişimciliğe dair bulguların destek kuruluşları, girişimciler, sivil toplum kuruluşları gibi aktörlerce teyit edilmesi ile uygulamaya aktarma çabaları öne çıkmaktadır. İnsan davranışları ile ilgili olan ve ağırlıkla tıp dünyası tarafından 
yürütülen nörobilim çalışmalarının ve nörobilimde kullanılan teknolojik ürün ve yöntemlerinin işletme literatüründe en önemli takipçisi ve uygulamacısı nöropazarlama disiplinidir. Nöropazarlama akademik araştırmalarından sağlanan bulgular iş dünyası tarafından yakından takip edilmekte tüketici araştırmaları ve pazarlama iletişim stratejileri bu sonuçlara göre şekillendirilmektedir. Sosyalbilimlerde literatürüzenginleşen ve uygulamacılar tarafından büyük kabul gören nöropazarlamada kullanılan araç, yöntem ve bulguların nörogirişimciliğe olan ilgiyi de arttıracağına kesin gözüyle bakılmaktadır.

Nörogirişimciliğin mevcut araştırmalardaki başarılı sonuçları ve önemli gelişme potansiyeli ile birlikte bazı sorunların da mevcudiyeti göze çarpmaktadır. En önemli sorunlardan biri, girişimci eylemlerinin her zaman bireysel bir eylem olmaması, aynı zamanda bir grubun eylemlerinden de kaynaklı olabilmesidir. $\mathrm{Bu}$ nedenle nörogirişimciliğe dair metodolojiler grup karar süreçlerini açıklamak için yeterli olmayabilir. Holan (2014), girişimcilik araştırmacılarının üç nedenden ötürü nörobilimi benimseme konusunda isteksiz davrandıklarını iddia etmektedir. Bunlar; multidisipliner araştırma yürütmedeki zorluk, yüksek maliyetler, çalışmaların karmaşıklığı ve yeniliğidir. Girişimcilik araştırmalarının nörobilimi benimseme konusundaki isteksizliğinin bir diğer nedeni, nörobilimin talep edeceği girişimcilik araştırma modelindeki değişikliklerden kaynaklanmaktadır. Nörobilim araștırmaları, sosyal bilimlerde talep edilenlerden oldukça farklı beceriler gerektirmektedir. Bilişsel bilimin teorik kavramları ve deneysel araçlarını etkili bir biçimde kullanmanın oldukça zor olması, girişimcilik akademisyenlerinin bu alanda gelişme sürecini uzatmaktadır. Mevcut bilim insanlarının çalışmalarında nörobilimden yararlanması için ciddi anlamda yeniden düzenlemeler yapılması ve farklı eğitim almaları gerekecektir. Girişimcilik alanının nörobilimi daha fazla benimsemesi, alanın daha paradigmatik çoğulculuğu kabul etmesinden geçmektedir. Nörobilim, bir zihinsel durum ile bir beyin aktivasyonu bölgesi arasında ilişki kurmayı ve daha sonra benzer bir beyin aktivasyonu biçimi tespit edildiğinde, söz konusu zihinsel durumun varlığını çıkarmayı içeren potansiyel ters çıarım problemleriyle doludur (Theodoridis ve Nelson, 2012). Poldrack'in (2008: 224) öne sürdüğü gibi, "tümdengelim mantığı açısından, ters çıkarım, sonucu onaylamanın mantıksal yanlışlığını yansıtır". Bu yüzden nörogirişimciliğin gelişmesinin önünde birtakım engeller bulunmaktadır. Ancak girişimcilikle ilgili daha derin bilimsel verilere ulaşmanın, girişimci düşünce/davranış/karar vermeyi daha iyi anlamanın ve girişimci bir toplum yaratmanın birinci kuralı "girişimci zihniyeti" anlamaktan geçmektedir. Nörogirişimcilik çalışmalarında dikkat edilmesi gereken hususlar bulunmaktadır. Bunların başında etik davranış ihlallerinin ortaya çıkabilmesidir. Çünkü nörobilim ve araçları sayesinde bireylerin yalnızca davranış nedenlerine dair veriler elde edilmekle kalmayıp, beynin belirli konularda manipüle edilmesi durumu bulunmaktadır. Bu durumun farklı çevrelerce değişik maksatlarla kullanılabileceği düşüncesi beraberinde bazı endişeleri de getirmektedir. $\mathrm{Bu}$ nedenle nörogirişimcilik araştırma ve çalışmalarında sosyal ve toplumsal endişeler dikkate alınarak, bilimsel etik kurallar çerçevesinde çalışılması gerekmektedir. Nörolojik ve biyolojik temelli yöntemlerin birlikte kullanılması farklı disiplinlerin bir araya gelerek uzlaşma sağlaması, nörogirişimciliğin ve sosyal bilimlerin farklı bilim dallarının gelişmesine olanak sağlayacaktır.

\section{Sonuç}

Sinirbilimleri ve girişimciliği birleştirerek, girişimciliğin bilişsel veya üstbilişsel yönleriyle ilgili hemen hemen her konunun nörofizyolojik ölçümler kullanılarak çalışılabilmesine ve incelenmesine olanak sağlayan nörogirişimcilik, girişimciliğe dair birçok problemin çözülmesi ve girişimci zihniyet/düşünce/karar/davranışlarının bütüncül bir yaklaşımla anlaşılmasını mümkün kılmaktadır. Nörogirişimcilik ayrıca nörobilimin olanaklarından faydalanmak suretiyle girişimci zihniyetin şifrelerini çözerek, toplumsal hayatın gelişimine katkı sağlamaktadır. Nörogirişimcilik alanında kısıtlı sayıda yapılan çalışmalara bakıldığında, henüz emekleme döneminde olduğu söylenebilir.

Nörogirişimcilikte kullanılan teknolojik araçların sayısının artması ve fiyatlarının araştırmacılar tarafından karşılanabilir olması ile nörogirişimciliğe yönelik akademik araştırmalarda önemli bir artış olacaktır. Elde edilen bilgilerin pratikte uygulanabilir olması, nitelikli girişimciliğin gelişmesine de önemli katkılar sağlayacaktır. Çok yönlü bir perspektiften bakıldığında bir taraftan nörobilim içerisinde gelişen yazın ve teknolojik imkân ve tekniklerden neogirişimcilik altdisiplini faydalanırken diğer taraftan nörogirişimcilik anlamında yapılacak olan çalışmalar sayesinde elde edilecek olan teknoloji ve yöntemler, sosyal bilimlerin diğer alanlarında da kullanılabilecektir.

\section{Kaynakça}

Ardichvili, A., Cardozo, R., ve Ray, S. (2003). A theory of entrepreneurial opportunity identification and development. Journal of Business Venturing, 18(1), 105-23.

Arı̆̆, E.ve Turan M. (2020). Video Duygu Analizi. Avrupa Bilim ve Teknoloji Dergisi, (Special Issue), 59-67.

Arenius, P. ve Minniti, (2005). M. Perceptual Variables and Nascent Entrepreneurship. Small Bus Econ 24, 233-247

Ajzen, I. (2005). Attitude, Personality and Behavior (2nd ed.). Poland, EU: Open University Press.

Barnea, A., H. Cronqvist ve S. Siegel (2010), "Nature or nurture: what determines investor behavior?" Journal of Financial Economics, 98 (3), 583-604.

Baron, R. (1998). Cognitive mechanisms in entrepreneurship: Why and when entrepreneurs think differently than other people. Journal of Business Venturing, 13, 275-294.

Baron, R.A. (2006). Opportunity recognition as pattern recognition: How entrepreneurs 'connect the dots' to identify new business opportunities. Academy of Management Perspectives, 20(1), 104-19.

Baucus, D.A., M.S. Baucus ve R.K. Mitchell (2014), "Lessons from the neural foundation of entrepreneurial cognition: the case of emotion and motivation," in J.R. Mitchell, R.K. Mitchell, and B. Randolph-Seng (eds), Handbook of Entrepreneurial Cognition, Cheltenham: Edward Elgar, pp. 254-315.

Berridge, K.C. ve M.L. Kringelbach (2008), "Affective neuroscience of pleasure: reward in humans and animals," Psychopharmacology, 199 (3), 457-80.

Bird., B. (1988). The operation of intentions in time: The emergence of the new venture. Entrepreneurship Theory and Practice., 17(1), s. 11-20.

Blair, E.S. (2010), "What you think is not what you think: unconsciousness and entrepreneurial behavior," in A.A. 
Stanton, M. Day, and I.M. Welpe (eds), Neuroeconomics and the Firm, Cheltenham, UK: Edward Elgar, pp. 50-65.

Boyd, N. ve Vozikis, G. (1994). "The Influence of Self-Efficacy on the Development of Entrepreneurial Intentions and Actions". Entrepreneurship Theory and Practice, s. 63-75.

Carter, R., Aldridge, S., Page ve M., Parker, S. (2019). The Human Brain Book. Division of Penguin Random House LLC, New York.

Camerer, C.F., ve Fehr, E. (2006). When does 'economic man' dominate social behavior? Science, 311(5757), 47-52.

Cacioppo, J.T., Petty, R.E. ve Morris, K.J. (1985). Semantic, evaluative, and self-referent processing: Memory, cognitive effort, and somatovisceral activity. Psychophysiology, 22(4), 371-84.

Coates J ve Herbert J (2007). Endogenous steroids and financial risk taking on a london trading floor. PNAS 105(16):61676172.

Custodio, P. (2010). Use of EEG as a Neuroscientific Approach to Advertising Research. Nature Reviews. Neuroscience, 11(4) 284-292.

Day M., Boardman M.C. ve Krueger N.F. (2017). Handbook of Research Methodologies and Design in Neuroentrepreneurship. In Colosio, M., Bellavitis, C., and Gorin, A.A., "Human psychophysiological and genetic approaches in neuroentrepreneurship". Elgar Publishing, Massachusetts.

Day M., Boardman M.C. ve Krueger N.F. (2017). Handbook of Research Methodologies and Design in Neuroentrepreneurship. In Holan P.B. and Couffe C., "Unpacking neuroentrepreneurship: conducting entrepreneurship research with EEG Technologies". Elgar Publishing, Massachusetts.

Ernst, B. ve M. Steinhauser (2015), "Effects of invalid feedback on learning and feedbackrelated brain activity in decisionmaking," Brain and Cognition, 99, 78-86.

Eser, Z., Isin, F. B. ve Tolon, M. (2011). Perceptions of marketing academics, neurologists, and marketing professionals about neuromarketing. Journal of Marketing Management, 27(7-8), s. $854-868$.

Gani, M., Reza, S., Rabi, M. ve Reza, S. (2015). Neuromarketing: Methodologies of Marketing Science. International Journal of Business and Management Study - IJBMS, Volume 2: Issue 2 294-298.

Guiso, L. ve Rustichini, A. (2011). Understanding the size and profitability of firms: The role of a biological factor (European University Institute Working Paper ECO 201101). Retrieved from http://cadmus.eui.eu/handle/1814/15642.

Martin de Holan, P., E. Ortiz-Terán, A. Turrero ve T. Alonso (2013), "Towards neuroentrepreneurship? Early evidence from a neuroscience study," Frontiers of Entrepreneurship Research, 33

(5); http://digitalknowledge.babson.edu/fer/vol33/iss5/12.

Hoskisson, R.E., J. Covin, H.W. Volberda ve R.A. Johnson (2011), "Revitalizing entrepreneurship: the search for new research opportunities," Journal of Management Studies, 48 (6), 1141-68; $\quad$ http://doi.org/10.1111/j.14676486.2010.00997.x

Krueger, N. (2000). The cognitive infrastructure of opportunity emergence. Entrepreneurship Theory \& Practice, 24(3): 523.

Krueger, N. ve Brazeal, D. (1994). Entrepreneurial potential and potential entrepreneurs. Entrepreneurship Theory and Practice, 18(3): 91-104.
Krueger, N., Reilly, M. ve Carsrud, A. (2000). Competing models of entrepreneurial intentions. Journal of Business Venturing, 15(5/6): 411-532.

Krueger, N. ve I. Welpe (2008), "Experimental entrepreneurship: a research prospectus and workshop," paper presented at the USASBE Annual Conference, San Antonio, TX, 10-13 January.

Krueger, N. (2011). Neuroentrepreneurship: what can entrepreneurship educators (\& practitioners) learn from neuroscience? December, 2011. NeuroPsychoEconomics Conference Proceedings.

Krueger, N. ve I. Welpe (2014), "Neuroentrepreneurship: what can entrepreneurship learn from neuroscience?" in M.H. Morris (ed.), Annals of Entrepreneurship Education and Pedagogy, Cheltenham, Edward Elgar, pp. 60-90.

Lawrence, A., Clark, L., Labuzetta, N.J. ve Sahakian, B. (2008). The Innovative Brain. Nature, 456, 168-169.

Laureiro-Martínez, D., N. Canessa, S. Brusoni, M. Zollo, T. Hare, F. Alemanno ve S.F. Cappa (2014), "Frontopolar cortex and decision-making efficiency: comparing brain activity of experts with different professional background during an explorationexploitation task," Frontiers in Human Neuroscience, $7, \quad 927$; http://doi.org/10.3389/fnhum.2013.00927.

McMullen, J.S., Wood M.S. ve Palich L.E. (2014), "Entrepreneurial cognition and social cognitive neuroscience," in J.R. Mitchell, R. Mitchell, and B. Randolph-Seng (eds), Handbook of Entrepreneurial Cognition, vol. 29, Cheltenham, UK/Northampton, MA: Edward Elgar, pp. 723-40.

Miljkovic, M. ve Alcakovic, S. (2010). Neuromarketing: Marketing research future. Menadzment, Marketing, Trgovina, 274-883.

Mitchell, R.K., ve Chesteen, S.A. (1995). Enhancing entrepreneurial expertise: Experiential pedagogy and the new venture expert script. Simulation \& Gaming, 26(3), 288-306.

Mitchell, R. K., Smith, B., Morse, E., Seawright, K., Peredo, A., ve McKenzie, B. (2002). Are entrepreneurial cognitions universal? Entrepreneurship Theory and Practice, 27(2).

Mitchell, R.K., Busenitz, L., Bird, B., Gaglio, C., McMullen, J., ve Morse, E. (2007). The central question in entrepreneurial cognition research. Entrepreneurship Theory \& Practice, 31(1), 1-27.

Morin, C. (2011). Neuromarketing: The New Science of Consumer Behavior. Symposium: Consumer Culture In Global Perspectıve Springer Science+Business Media, s. 131-135.

Ngrams, (2020). Analiz Raporlar1, https://books.google.com/ngrams/Erişim:29.12.2020

Nicolaou, N. ve S. Shane (2014), "Biology, neuroscience, and entrepreneurship," Journal of Management Inquiry, 23 (1), 98-100.

Nicolaou, N., Patel, P. C. ve Wolfe, M. T. (2018). Testosterone and Tendency to Engage in Self-Employment. Management Science.

Nofal, A. M., Nicolaou, N. ve Symeonidou, N. (2017). Biology and Entrepreneurship. In G. Ahmetoglu, T. ChamorroPremuzic, B. Klinger and T. Karcisky (Eds.), The Wiley Handbook of Entrepreneurship: Wiley.

Nordqvist, C. (2014), "What is neuroscience?" Medical News Today,

Erişim:29.12.2020 http://www.medicalnewstoday.com/. 
Ortiz-Terán, E., A. Turrero, J.M. Santos, P.T. Bryant, T. Ortiz, E. Ortiz-Terán ve T. Ortiz (2014), "Brain cortical organization in entrepreneurs during a visual Stroop decision task," Clinical, Cosmetic and Investigational Dentistry, 6, 45-56.

Patel, P.C. ve J.O. Fiet (2010), "Enhancing the internal validity of entrepreneurship experiments by assessing treatment effects at multiple levels across multiple trials," Journal of Economic Behavior and Organization, 76, 127-40.

Peelen, M.V., ve Kastner, S. (2014). Attention in the real world: toward understanding its neural basis, Trends in Cognitive Sciences, http://dx.doi.org/10.1016/j.tics.

Perez, V. (2017), "Brain-driven entrepreneurship research: a review and research agenda," in M. Day, M. Boardman, and K. Norris (eds), Handbook of Research Methodologies and Design in Neuro-entrepreneurship, Cheltenham: Edward Elgar.

Poldrack, R. A. (2008). The role of fMRI in cognitive neuroscience: Where do we stand? Current Opinion in Neurobiology, 18, 223-227.

Santos, Susana C., Sílvia F. Costa, Xaver Neumeyer veAntónio Caetano. (2016). Bridging Entrepreneurial Cognition Research and Entrepreneurship Education: What and How. In Annals of Entrepreneurship Education and Pedagogy, ed. Michael H. Morris and Eric Liguori, 83-108. Cheltenham: Edward Elgar Publishing.

Sarasvathy, D.K., Simon, H.A. ve Lave, L. (1998). Perceiving and managing business risks: Differences between entrepreneurs and bankers, Journal of Economic Behavior \& Organization, $33(2), 207-25$.

Shane, S. (2000). Prior knowledge and the discovery of entrepreneurial opportunities. Organization Science, 11(4), 448-69.

Shane, S. (2003). A General Theory of Entrepreneurship: The Individual-Opportunity Nexus. Cheltenham, UK and Northampton, MA, USA: Edward Elgar.

Shapero, A., (1985). Why entrepreneurship? Journal of Small Business Management, 23(4): 1-5.

Shapero, A. ve Sokol, L. (1982). The social dimensions of entrepreneurship. In The Encyclopedia of entrepreneurship. Englewood Cliffs, NJ: Prentice Hall.

Singh, R.P. ve Ronch, J.L. (2011). Changing Entrepreneurial Cognitive Processes with Age: A Conceptual Discussion Based on Neuroscience. Journal of Marketing Development and Competitiveness, Vol. 5(6), 94-103.

Soon, C.S., M. Brass, H.-J. Heinze ve Haynes J.-D. (2008), "Unconscious Determinants of Free Decisions In The Human Brain," Nature Neuroscience, 11 (5), 543-5; http://doi.org/10.1038/nn.2112.

Simon, H. 1997/1963. Administrative Behaviour (4th ed.). New York: Free Press.

Şeşen, H. ve Basım, N. (2012). Demografik Faktörler ve Kişiliğin Girişimcilik Niyetine Etkisi: Spor Bilimleri Alanında Öğrenim Gören Üniversite Öğrencileri Üzerine Bir Araştırma. Ege Akademik Bakış, 12, s. 21-28.

Theodoridis, A. G. ve Nelson, A. J. (2012). Of BOLD claims and excessive fears: A call for caution and patience regarding political neuroscience. Political Psychology, 33, 27-43.

Toga, A.W. ve P.M. Thompson (2005), "Genetics of brain structure and intelligence," Annual Review of Neuroscience, 28 (1), 1-23.

Treadway MT, Buckholtz JW, Schwartzman AN, Lambert WE, Zald DH (2009) Worth the 'EEfRT'? The Effort Expenditure for Rewards Task as an Objective Measure of Motivation and Anhedonia. PLoS ONE 4(8): e6598.

Treadway, M. T., Buckholtz, J. W., Cowan, R.L., Woodward, N.D., Li, R., Ansari, M.S., Baldwin, R. M., Schwartzman, A. N., Kessler, R. M. ve Zald, D. H. (2012). Dopaminergic Mechanisms of Individual Differences in Human Effortbased decision-making. The Journal of Neuroscience, 32 (18), 6170-6176.

Tumasjan, A., Welpe, I.M., and Spörrle, M. (2012). Easy now, desirable later: The moderating role of temporal distance in opportunity evaluation and exploitation. Entrepreneurship Theory and Practice, 37(4), 859-88.

White, R.E., Thornhill S. ve Hampson, E. (2006). Entrepreneurs and evolutionary biology: The relationship between testosterone and new venture creation. Organizational Behavior and Human Decision Processes, 100, 21-34.

Wood, M.S. ve D.W. Williams (2014), "Opportunity evaluation as rule-based decision making," Journal of Management Studies, 51 (4), 573-602; http://doi.org/10.1111/ joms.12018.

Wolfe, M. T. ve Patel, P. C. (2017). Two Are Better Than One: Cortisol As a Contingency In The Association Between Epinephrine and Self-employment. Journal of Business Venturing Insights, 8: 78-86.

Zaro, M.A., Fagundes, L.C., Rocha, F.T. and Nunes, W.S. (2016). Cognitive brain mapping used in the study of entrepreneurial behavior - pilot test with the use of electroencephalogramEEG during the process of identification of business opportunities. American Journal of Educational Research, 2016, 4 (6), 472-478.

Zhang, Z., M.J. Zyphur, J. Narayanan, R.D. Arvey, S. Chaturvedi, B.J. Avolio ve G. Larsson (2009), "The genetic basis of entrepreneurship: effects of gender and personality," Organizational Behavior and Human Decision Processes, 110 (2), 93-107. 